\title{
Effects of metal ions on osteoblast-like cell metabolism and differentiation
}

\author{
Zhi Lin Sun, ${ }^{* *}$ John C. Wataha, ${ }^{3}$ and Carl T. Hanks ${ }^{2}$ \\ Departments of ${ }^{1}$ Biological Materials and Sciences and ${ }^{2}$ Oral Medicine, Pathology, and Surgery, The University of \\ Michigan School of Dentistry, Ann Arbor, Michigan 48109-1078; and ${ }^{3}$ Department of Oral Rehabilitation, Medical \\ College of Georgia School of Dentistry, Augusta, Georgia 30912-1260
}

The objective of this study was to evaluate the effects of metal ions, which may be released from orthopedic or dental implants, on osteoblast metabolism and differentiation. ROS $17 / 2.8$ cells were cultured in F-12 medium for 7 days. Then $\mathrm{Al}^{+3}, \mathrm{Co}^{+2}, \mathrm{Cr}^{+3}, \mathrm{Ni}^{+2}, \mathrm{Ti}^{+4}$, and $\mathrm{V}^{+3}$ were added at concentrations less than their cytotoxic concentrations. After 3 days, DNA synthesis, succinate dehydrogenase activity, alkaline phosphatase (ALP) activity, and culture calcification were assessed. Northern blots were performed for ALP, osteocalcin $(\mathrm{OCN})$, and osteopontin (OPN) mRNA transcription. The data indicated that $\mathrm{Cr}^{+3}$ and $\mathrm{Al}^{+3}$ had few inhibitory effects on ROS cell metabolism below their cytotoxic concentrations, $\mathrm{Ni}^{+2}, \mathrm{Co}^{+2}, \mathrm{Ti}^{+4}$, and $\mathrm{V}^{+3}$ affected all these parameters of ROS cell metabolism at concentrations below cytotoxic levels. For RNA analysis, $\mathrm{Al}^{+3}$ significantly suppressed the expression of ALP, OCN, and OPN at both cytotoxic and noncytoxic concentrations. $\mathrm{Co}^{+2}$ specifically suppressed ALP expression at cytotoxic concentrations. $\mathrm{Cr}^{+3}$ and $\mathrm{Ni}^{+2}$ inhibited $\mathrm{OCN}$, OPN, and ALP gene expression only at cytotoxic concentrations. For $\mathrm{Ti}^{+4}$ and $\mathrm{V}^{+3}$ ions, gene expression at cytotoxic levels was not significantly affected as compared with the effects at noncytotoxic level. These results show that metal ions may alter osteoblast behavior even at subtoxic concentrations, but do not always affect the expression of all genes similarly. (c) 1997 John Wiley \& Sons, Inc.

\section{INTRODUCTION}

Metals and alloys have a wide range of applications as prosthetic materials for bone and tooth tissue reconstruction. The most common metals or alloys in orthopedics and dentistry are cobalt-chromium-nickel, titanium-aluminum-vanadium, and commercially pure (cp) titanium. The suitable mechanical and physical properties of these materials have made them attractive as implant materials. However, in vivo corrosion of these metals is a major potential disadvantage of these implants. Generally, corrosion can cause two kind of changes: 1) reduction of the mechanical properties and shortening of the implant life time, and 2) harmful reactions to the host body both locally and systemically brought on by products of corrosion.

A number of investigations have demonstrated that metal ions can be released from metallic implants as the result of corrosion. ${ }^{1-3}$ Trace element analysis has shown that metal ions can be localized in blood or

*To whom correspondence should be addressed at the Department of Biological Materials and Sciences, School of Dentistry Room 5223, University of Michigan, 1011 N. University Avenue, Ann Arbor, MI 48109-1078. serum, ${ }^{4}$ urine, ${ }^{5}$ and other organs, ${ }^{6-8}$ as well as in bone tissue adjacent to implants.,10 The biologic consequences of these released ions on the tissues or cells have been extensively studied in vitro and in vivo. Recent research results have shown that at concentrations less than those which cause a $50 \%$ depression in general cell activity, Ti and Co ions still can inhibit the specific cellular functions such as alkaline phosphatase (ALP) activity, extracellular calcification, and bone-specific gene expression. ${ }^{11,12}$

To identify a material as biocompatible to bone, it is more informative to pay attention to the effect of the material on specific cellular functions than to evaluate general cytotoxicity. Previous studies have investigated the effects of metal ions and alloys on bone tissue function. Wataha et al. compared the cytotoxicity of several metal ions by using a fibroblast cell line (Balb / c 3T3) and osteoblast-like cell line (ROS 17/2.8). For Ti the osteoblast-like cell line showed more sensitivity than the fibroblast cell line. ${ }^{13}$ Haynes et al. reported that Ti-6Al-4V particles elicited high levels of cytokines and prostaglandin $\mathrm{E}_{2}$ from human monocytes. These biologic mediators have the ability to initiate an inflammatory response and bone resorption. ${ }^{14}$ Furthermore, Massa et al. compared titanium and hydroxyap- 
atite (HA) on ALP activity as well as the response to parathyroid hormone (PTH) in rat calvarium cells. The results indicated that cells contacting HA have higher ALP activity and higher response to PTH than cells contacting titanium. ${ }^{15}$ Puleo et al. found that neither Ti-6Al-4V alloy nor HA ceramic had an effect on expression of the bone matrix protein genes of osteonectin and osteopontin (OPN) ${ }^{16}$

Although these studies provide valuable information about cellular response to implant materials, the mechanisms of cell-implant interactions are still unclear. Many experimental problems need to be solved. First, the cytotoxicity of a material is often evaluated by a fibroblast culture in vitro. To some extent, the results can explain how cytotoxic the material is. But, as we know, cells of different origins have different cellular reactions to foreign bodies. Thus, the results from fibroblasts should not predicate the cytotoxicity for bone cells or other tissue cells. Second, alloys, rather than component ions, are frequently studied for biocompatibility. When using the alloy, it is difficult to determine which element of the alloy is responsible for the adverse action. In addition, the conventional cytotoxicity evaluation which focuses on the viability of cells does not explain the material's influence on specific cellular functions and differentiation processes.

In this article, we have evaluated the effect of $\mathrm{Cr}$, $\mathrm{Al}, \mathrm{Ni}, \mathrm{Co}, \mathrm{Ti}$, and $\mathrm{V}$ ions, which are ions which may be released from metallic implants in vivo, ${ }^{2,8}$ on osteoblastlike cell metabolism. We have tried to explain how these ions, at cytotoxic and noncytotoxic concentrations, affect the metabolism and bone-specific gene expression of osteoblasts. Since the bone tissue is probably chronically exposed to low levels of ions released from the implant, the focus of this study is on the effects of sublethal levels of the metal ions. Our hypothesis is that metal ions can affect bone cell differentiation and cell-specific functions at sublethal concentrations. Information from this study should help clarify the effects of metal ions on bone tissue and improve our understanding of bone-implant interactions.

\section{MATERIALS AND METHODS}

Six metal ions, $\mathrm{Al}^{+3}, \mathrm{Co}^{+2}, \mathrm{Cr}^{+3}, \mathrm{Ni}^{+2}, \mathrm{Ti}^{+4}$, and $\mathrm{V}^{+3}$, were selected for this study because they are basic components of current metallic implants in orthopedics and dentistry. All metal salts were purchased as the chlorides (Aldrich, Milwaukee, WI) and stock solutions were prepared in sterile water, then were diluted such that $10 \mu \mathrm{L}$ would provide the desired final concentration in $200 \mu \mathrm{L}$ of F-12 culture medium. Pilot experiments showed that addition of these concentra- tions altered $\mathrm{pH}$ by $<0.05$, and induced no precipitation.

To measure cellular proliferation and metabolism, the DNA synthetic rate $\left({ }^{3} \mathrm{H}-\mathrm{TdR}\right.$ incorporation) and mitochondrial dehydrogenase activity [succinate dehydrogenase (SDH)] were used. Previous studies have shown that both of them were reliable and sensitive parameters for studying cellular growth and viability, and have been extensively used in the determination of cytotoxicity of metal ions as well as other biomaterials. ${ }^{17,18}$ To determine the expression of osteoblastrelated phenotypes, ALP activity was measured, von Kossa histologic staining was used to measure culture mineralization. Finally, to evaluate cellular differentiation for the osteoblast-like cells, expression of ALP (cDNA for mouse liver/bone/kidney ALP was a gift from Dr. Rennie Franceschi (University of Michigan, School of Dentistry, Ann Arbor, MI), osteocalcin $[(\mathrm{OCN})$ mouse cDNA from Genetics Institute, Cambridge, MA], and OPN (mouse cDNA from Dr. G. A. Rodan, Merck Sharp and Dohme, West Point, PA) genes were measured using Northern blot analysis. $\mathrm{OCN}$ and OPN have been identified as noncollagenous extracellular proteins in bone matrix and are synthesized by osteoblasts and osteoblast-like cells. ${ }^{19}$ Their biologic function in bone tissue is not completely known, but they generally relate to the formation, growth, and regulation of bone tissue and mineralization. Since they are synthesized mainly by osteoblasts, they usually are selected as unique markers for studying bone cell differentiation and bone tissue mineralization. As result, in the study of osseous tissue integration with biomaterials, the expression of bone-specific proteins in the local region is an important signal to indicate when bone tissue formation is occurring, and may give insight into the responsiveness of bone cells to the new environment created by the artificial implant.

Concentrations of metal ions were selected as follows. Concentrations which caused a 50\% reduction of SDH activity in ROS cells were used as the highest concentrations, except for $\mathrm{Al}$ and $\mathrm{Cr} .{ }^{13}$ Subsequent concentrations (four others) were decreased sequentially by half. The ions and their concentrations ranges are shown in Table I. For $\mathrm{Al}$ and $\mathrm{Cr}$, the maximum concentrations which did not cause precipitation in the medium were used, since 50\% reduction in SDH activity could not be reached. The DNA synthesis and ALP activity were performed on these five concentrations. Because of interactions between the $\mathrm{Cr}, \mathrm{Al}, \mathrm{Ni}$, and $\mathrm{V}$ ion solutions and von Kossa staining solution, the mineralization assay (von Kossa stain) was performed only for $\mathrm{Ti}$ and $\mathrm{Co}$ ions. Furthermore, effects of the ions on gene expression of these cells were determined at two concentrations. One concentration was selected because it was not cytotoxic by the SDH activity assay and another concentration was selected because it was 
TABLE I

Metal Ion Concentrations and Sources

\begin{tabular}{cccl}
\hline $\begin{array}{c}\text { Metal } \\
\text { Ion }\end{array}$ & \multicolumn{1}{c}{$\begin{array}{c}\text { Conc. Range Tested } \\
(\mu \mathrm{mol} / \mathrm{L})^{*}\end{array}$} & $\begin{array}{c}\mathrm{TC}_{50} \text { Conc. } \\
(\mu \mathrm{mol} / \mathrm{L})^{+}\end{array}$ & \multicolumn{1}{c}{ Source } \\
\hline $\mathrm{Al}^{+3}$ & $195,390,780,1560,3120$ & $3120^{\ddagger}$ & $\mathrm{AlCl}_{3}{ }^{3}$ \\
$\mathrm{Co}^{+2}$ & $13,26,52,104,208$ & 208 & $\mathrm{CoCl}_{2} \cdot 6 \mathrm{H}_{2} \mathrm{O}$ \\
$\mathrm{Cr}^{+3}$ & $120,240,480,960,1920$ & $1920^{\|}$ & $\mathrm{CrCl}_{3} \cdot 6 \mathrm{H}_{2} \mathrm{O}$ \\
$\mathrm{Ni}^{+2}$ & $38,76,152,304,608$ & 608 & $\mathrm{NiCl}_{2} \cdot \mathrm{H}_{2} \mathrm{O}$ \\
$\mathrm{Ti}^{+4}$ & $13,26,52,104,208$ & 208 & $\mathrm{TiCl}_{4}{ }^{\S}$ \\
$\mathrm{V}^{+3}$ & $1.25,2.5,5,10,20$ & 20 & $\mathrm{~V} \mathrm{Cl}_{3}{ }^{\S}$ \\
\hline
\end{tabular}

* Lowest and highest concentrations tested.

${ }^{+}$Concentration required to reduce SDH activity by $50 \%$ compared to controls (without metal ions).

$\$ 3120 \mu \mathrm{mol} / \mathrm{L}$ of $\mathrm{Al}$ only suppressed SDH activity by $20 \%$. Higher concentrations could not be used because of precipitation.

$\S$ Obtained from atomic absorption standard solutions.

$\| 1920 \mu \mathrm{mol} / \mathrm{L}$ of $\mathrm{Cr}$ did not suppress SDH activity significantly, but was the highest concentration which could be used because of precipitation.

significantly cytotoxic by the SDH activity assay. Since $\mathrm{Al}$ and $\mathrm{Cr}$ were not cytotoxic at any concentration tested, the highest and lowest concentrations were chosen for gene expression tests.

ROS 17/2.8 osteoblast-like cells were kindly given to us by Dr. Robert Majeska (Mt. Sinai Hospital, New York, NY) and were maintained in F-12 medium (Gibco, Grand Island, NY) containing: $28 \mathrm{mM}$ HEPES (Calbiochem, La Jolla, CA), $1.1 \mathrm{mM} \mathrm{CaCl}$ (Allied Chemical, Monistown, NJ), 5\% NuSerum (Collaborative Res, Bedford, MA), and $25 \mathrm{mM}$ L-glutamine and $125 \mathrm{U} / \mathrm{mL}$ penicillin-streptomycin (GIBCO). Cells were plated at 30,000 cells $/ \mathrm{cm}^{2}$ in $200 \mu \mathrm{L}$ of medium in 96-well plates (Costar, Cambridge, MA) and were kept at $37^{\circ} \mathrm{C}$ in a humidified $95 \%$ air $-5 \% \mathrm{CO}_{2}$ atmosphere. At 3-4 days, the medium was changed. At 7 days, the cultured cells became confident. Control wells were fed with the following medium: F-12 medium and $50 \mu \mathrm{g} / \mathrm{mL}$ ascorbic acid (AA) (J. T. Baker, Phillipsburg, NJ), $10 \mathrm{mM} \beta$-glycerophosphate (GP; Sigma, St. Louis, MO), and $100 \mathrm{n} M$ dexamethasone (Dex; Sigma, St. Louis, MO). Experimental wells were treated with various concentrations of metal ions in addition to medium supplements at 7 days. At 10 days, determinations of cell proliferation, mineralization and specific mRNA expression were carried out. For every test group, there were a total of six replicates.

The procedure for $\left[{ }^{3} \mathrm{H}\right]$ thymidine (TdR) incorporation is described in detail elsewhere. ${ }^{20}{ }^{3} \mathrm{H}-\mathrm{TdR}$ was purchased at $1 \mu \mathrm{Ci} / \mathrm{mL}$ and $65 \mathrm{Ci} / \mathrm{mmol}$ (ICN, Irvine, CA). ${ }^{3} \mathrm{H}-\mathrm{TdR}$ at a final concentration of $0.05 \mu \mathrm{Ci} / \mathrm{mL}$ was added to the cells in the culture for $2 \mathrm{~h}$. At the end of incubation, the cultures were washed by $5 \%$ trichloroacetic acid (TCA) solution at $4^{\circ} \mathrm{C}$ three times, and the solution was removed. $100 \mu \mathrm{L} /$ well of $6.7 \mathrm{~N}$ perchloric acid (PCA) solution was added and stirred for $5 \mathrm{~min}$. Then $75 \mu \mathrm{L}$ of the PCA extract was added to
$3 \mathrm{~mL}$ Bio-Safe II liquid scintillation solution (Research Products, Mount Prospect, IL) and allowed to rest for $12 \mathrm{~h}$. Scintillation counting [counts per minute (cpm)] was performed in a 1209 RackBeta liquid scintillation counter (LKB Wallac, Turku, Finland) after $12 \mathrm{~h}$.

Succinate dehydrogenase (SDH) activity was determined by the colorimetric MTT method [a tetrazolium salt: 3-(4,5-dimehtyl-thiazoly(-2)-2,5-diphenyl tetrazolium bromide] (Sigma). ${ }^{21}$ Then $100 \mu \mathrm{L} /$ well 1\% MTT solution was added and incubated with the cells at $37^{\circ} \mathrm{C}$ for $1 \mathrm{~h}$. The MTT solution was removed and cells were washed with phosphate-buffered saline (PBS). The blue formazan product was dissolved in $100 \mu \mathrm{L} /$ well dimethyl sulfoxide (DMSO), and the absorption (Abs) of MTT-formazan was read at $560 \mathrm{~nm}$.

Measurement of ALP activity was performed as described by Bessey et al. ${ }^{22}$ Briefly, cultured cells were rinsed with PBS and $100 \mu \mathrm{L} /$ well of $50 \mathrm{mM}$ Tris- $\mathrm{HCl}$ buffer ( $\mathrm{pH} 7.45)$ was added and the cultures were stored at $-20^{\circ} \mathrm{C}$ until ready for assay. The cultures were incubated at $37^{\circ} \mathrm{C}$ for $10 \mathrm{~min}$ with $20 \mu \mathrm{L} /$ well enzyme substrate mixture solution containing: $2 \mathrm{mM}$ $\mathrm{Na}_{2}$-nitrophenylphosphate ( $\left.\mathrm{Na}_{2}-\mathrm{PNPP}\right)$ (Sigma) and $2 \mathrm{mM} \mathrm{MgCl}_{2}$ in $0.1 \mathrm{M}$ 2-amino-2methyl-1-propanol buffer ( $\mathrm{pH}$ 10.5) in individual wells of a 96-well tissue plate. The reaction was stopped with $100 \mu \mathrm{L} /$ well of $1 \mathrm{~N} \mathrm{NaOH}$. Enzyme activity was read at $405 \mathrm{~nm}$. Protein concentration was determined using a micro-BCA protein assay kit (Pierce, Rockford, IL). The ALP activity was expressed in terms of micromoles per minute per milligram protein.

Mineralization of the cultures was measured by von Kossa stain. The matrix was washed with PBS, fixed by sequential treatment of the cultures with 70 , 90 , and $100 \%$ ethanol for $5 \mathrm{~min}$, respectively, and then hydrated with $\mathrm{H}_{2} \mathrm{O}$. The fixed cultures were treated with $5 \%$ silver nitrate solution $100 \mu \mathrm{L} /$ well in the dark at $37^{\circ} \mathrm{C}$ for $1 \mathrm{~h}$. The excess silver nitrate solution was then completely washed away by double-distilled $\mathrm{H}_{2} \mathrm{O}$ $\left(\mathrm{dd}-\mathrm{H}_{2} \mathrm{O}\right)$ and the culture plate was exposed to strong light for $30 \mathrm{~min}$. The metallic silver produced brownblack precipitates, and the optical density of the stained matrix was measured at $405 \mathrm{~nm}$.

Total RNA isolation and Northern blot analyses were carried out by the method as described by Towle. ${ }^{23}$ Total RNA was extracted and purified by using phenol-chloroform and isoamyl alcohol. RNA was precipitated in sodium acetate and collected by centrifugation at $10,000 \times g$ for $20 \mathrm{~min}$ at $4^{\circ} \mathrm{C}$. A total of $20 \mu \mathrm{g}$ of total RNA was electrophoresed in $0.8 \%$ agarose/formaldehyde gel and blotted onto a nylon membrane with $20 \times \operatorname{SSC}(\mathrm{NaCl}$, sodium citrate, and $\mathrm{NaOH})$ solution. After crosslinking, prehybridization was performed in $50 \%$ formamide, $5 \times$ SSC, $5 \times$ Denhardt's solution, $50 \mathrm{mM}$ phosphate buffer ( $\mathrm{pH}$ 6.5), 1\% sodium dodecyl sulfate (SDS), $250 \mu \mathrm{g} / \mathrm{mL}$ salmon sperm DNA at $42^{\circ} \mathrm{C}$ for $4 \mathrm{~h}$. Hybridization was performed at $45^{\circ} \mathrm{C}$ 


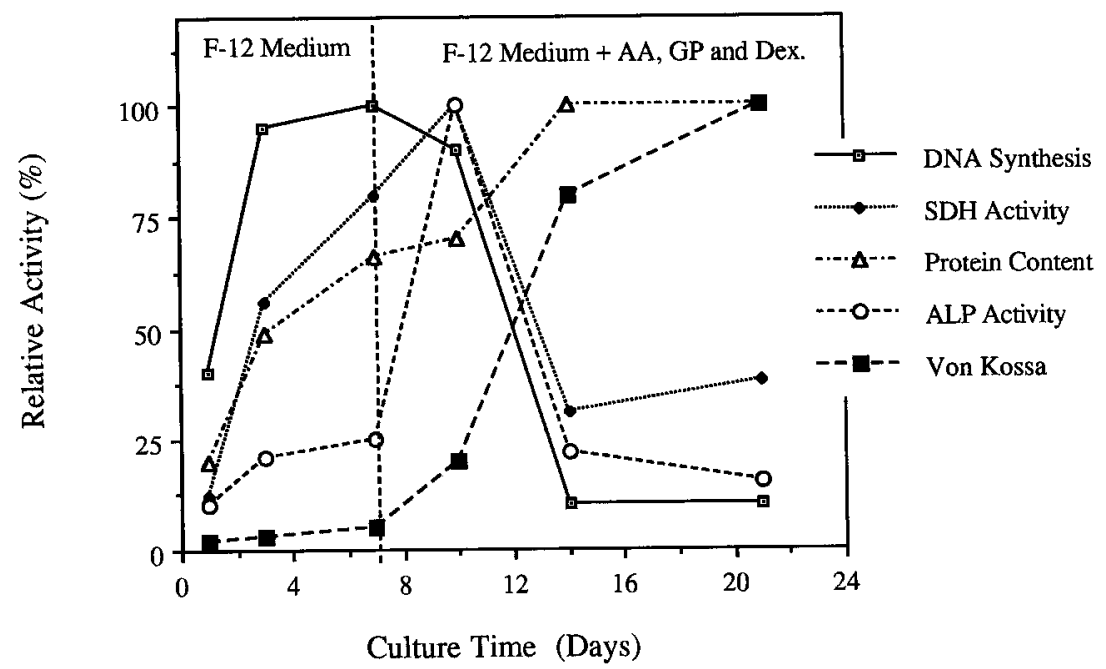

Figure 1. Metabolism characteristics of osteoblast-like ROS 17/2.8 cells at different culture times. Cells were plated at 30,000 cells $/ \mathrm{cm}^{2}$ and cultured in F-12 medium from 7 days. After 7 days, cells were cultured in F-12 medium with AA, GP, and Dex. The DNA synthesis, SDH activity, ALP activity, total protein content, and von Kossa stain were performed on 1, 3, 7, 10,14 , and 21 days, respectively. All terms are described as the relative activity, i.e. the percentage of the maximum level of measurements.

for $18 \mathrm{~h}$ in the same buffer containing $1 \times 10^{6} \mathrm{dpm}$ [ $\left.{ }^{32} \mathrm{P}\right] \mathrm{dCTP}-$ labeled denatured cDNA probe, using a random primer kit (Boehringer Mannheim, Indianapolis, IN). After hybridization, blots were washed twice at room temperature and once at $65^{\circ} \mathrm{C}$ with $2 \times$ SSC and $0.1 \%$ SDS and then twice at $65^{\circ} \mathrm{C}$ with $1 \times$ SSC and $0.1 \%$ SDS. Blots were visualized by autoradiography.

Normal cell metabolic characteristics were tested from 1 to 21 days to select the best time to add the metal ions and measure cell response. Figure 1 shows the DNA synthesis rate, SDH activity, ALP activity, total protein content, and matrix calcification (von Kossa) over 21 days in culture with no metal ions. All parameters are described as percent activity relative to controls. From data shown in Figure 1, the 10-day cultures were determined to be the most suitable cultures for testing the effects of the metals. This time was chosen for several reasons. Although the mineralization was still moderate compared to the 14- and 21-day cultures, the ALP activity, SDH activity, and DNA synthesis rate were highest at 10 days. In addition, the expression of ALP, OCN, and OPN mRNA were also detectable at this time. Figure 2 presents the Northern blot results of gene expression at 10 days without metals present. Throughout these experiments, the exposure time of the metals to the ROS cells was 3 days (from days 7 to 10). We chose this interval because the early addition of the metal ions would have the greatest chance of inhibiting cell proliferation and changing cell phenotypes.

\section{RESULTS}

Table I shows the concentration required to cause a $50 \%$ decrease in SDH activity $\left(\mathrm{TC}_{50}\right)$ for each ion. For aluminum, only the $\mathrm{TC}_{25}$ concentration could be determined, which was the concentration required to cause a $25 \%$ decrease of $\mathrm{SDH}$ activity. For $\mathrm{Cr}$, no suppression of SDH activity was evident at the highest concentration.

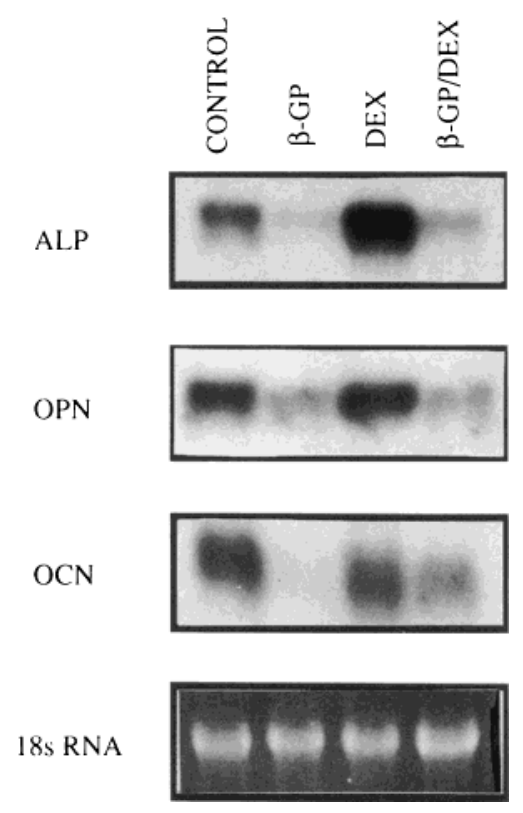

Figure 2. ALP, OCN, and OPN gene expression by ROS $17 / 2.8$ cells. RNA was isolated from 10-day cultured cells. Lane 1: cells were cultured only in F-12 medium with AA. Lane 2: cells were cultured in F-12 medium with AA and GP. Lane 3: cells were cultured in F-12 medium with AA and Dex. Lane 4: cells were cultured in F-12 medium with AA, GP, and Dex. Results show that Dex can stimulate the expression of ALP gene, but not of OCN and OPN genes in ROS $17 / 2.8$ cells. 
The only significant effect of the $\mathrm{Cr}$ ion on the ROS cells was to suppress the DNA synthesis about $50 \%$ at the $\mathrm{TC}_{50}$ value (Fig. 3). SDH and ALP activities were maintained at high and stable levels (Fig. 3). RNA analysis indicated that $\mathrm{Cr}$ ion did not inhibit ALP, OCN, and OPN gene expresson at $120 \mu \mathrm{mol} / \mathrm{L}$, but significantly inhibited ALP, OCN, and OPN gene expression at $1920 \mu \mathrm{mol} / \mathrm{L}$ (Fig. 4 and Table II).

A similar pattern for DNA synthesis, SDH activity, and ALP activity were observed for $\mathrm{Al}$ ion. However, the DNA synthesis rate was inhibited about $40 \%$ at $1560 \mu \mathrm{mol} / \mathrm{L}$ (Fig. 3). Compared to controls, SDH activity and ALP activity were maintained at relatively stable levels (Fig. 3). RNA analysis demonstrated that $\mathrm{Al}$ ions significantly inhibited the ALP, OCN, and OPN gene expression at both $\mathrm{TC}_{25}$ concentration $(3120 \mu \mathrm{mol} / \mathrm{L})$ and noncytotoxic concentration $(195 \mu \mathrm{mol} / \mathrm{L})$. The ALP gene expression was almost completely suppressed (Fig. 4 and Table II).

ROS cells showed similar responses to $\mathrm{Co}, \mathrm{Ni}, \mathrm{Ti}$, and $\mathrm{V}$ ions. For these ions, cytotoxicity was a function of the concentrations below the $\mathrm{TC}_{50}$ values. As the concentration increased, the cytotoxicity of these ions was also increased. The DNA synthesis was the most sensitive of the metabolic assays (Fig. 3). In addition, it was found that the presence of $\mathrm{Co}$ and $\mathrm{Ti}$ ions could inhibit the mineralization process during 3 days exposure to ROS, 17/2.8 cells (Fig. 3). However, the effects
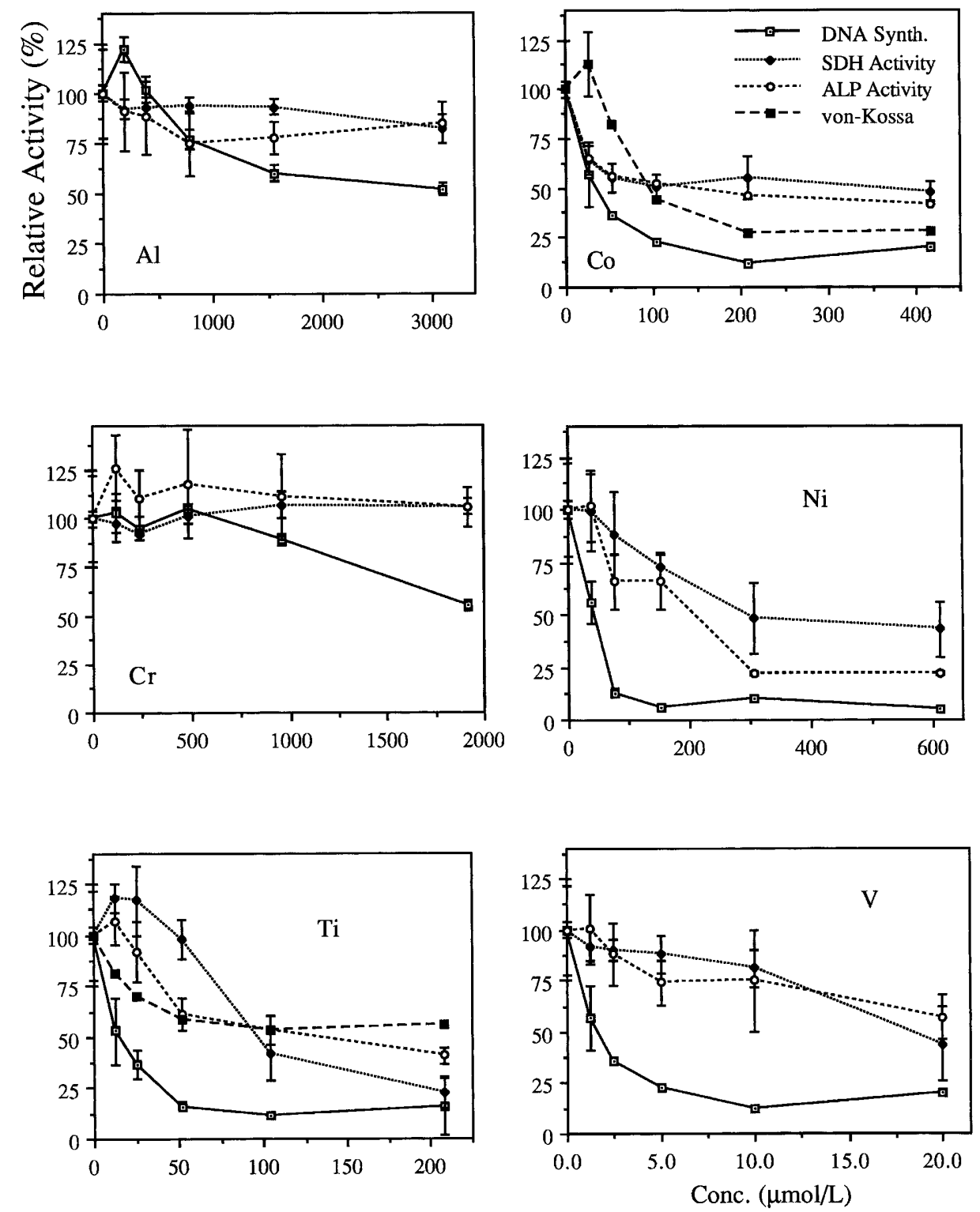

Figure 3. Effects of six metal ions on ROS $17 / 2.8$ cell DNA synthesis, SDH activity, ALP activity, and mineralization (von Kossa stain). Al, Co, Cr, Ni, Ti, and V ions at five different concentrations were added to ROS cells for 3 days. Because of interactions between the $\mathrm{Cr}, \mathrm{Al}, \mathrm{Ni}$, and $\mathrm{V}$ ion solutions and the von Kossa stain solution, von Kossa staining was performed only for Ti and Co ions. All test items are expressed as a percentage of control samples. 


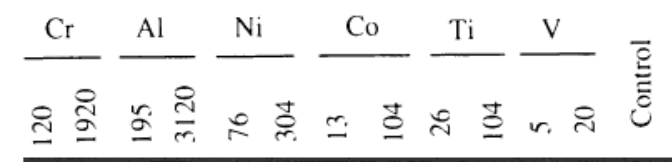

ALP

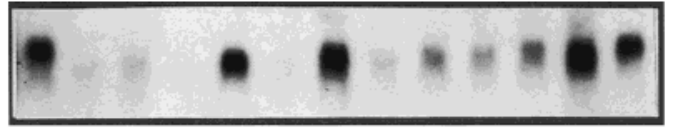

OPN

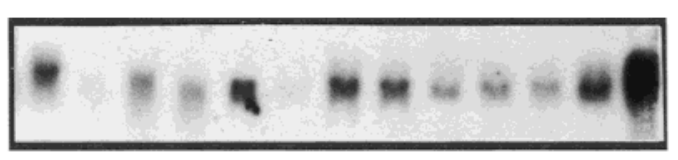

OCN

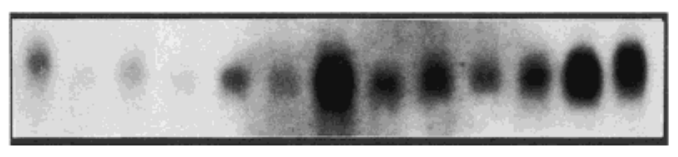

18 S RNA

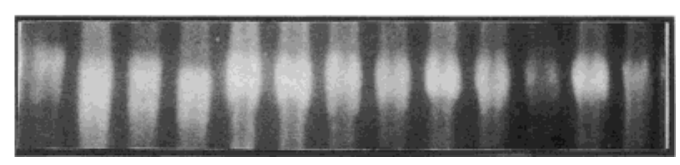

Figure 4. Effects of six metal ions on ROS $17 / 2.8$ cell expression of ALP, OCN, and OPN genes. For each ion, there were two concentrations $(\mu \mathrm{mol} / \mathrm{L})$ selected for the RNA analysis.

of these ions on gene expression did not have the same pattern (Fig. 4 and Table II). Ni ion suppressed OCN gene, but did not suppress the ALP and OPN mRNA expression at the noncytotoxic concentration (76 $\mu \mathrm{mol} / \mathrm{L})$, and significantly inhibited all of them at cytotoxic concentration $(304 \mu \mathrm{mol} / \mathrm{L})$. Co ion did not affect levels of mRNA of ALP, OCN, and OPN at noncytotoxic concentration $(13 \mu \mathrm{mol} / \mathrm{L})$, but did suppress ALP and OCN mRNA significantly at the cytotoxic concentration $(104 \mu \mathrm{mol} / \mathrm{L})$. Ti and $\mathrm{V}$ did not significantly inhibit the expression of these three mRNA levels at either cytotoxic or noncytotoxic concentrations.

\section{DISCUSSION}

ROS 17/2.8 osteoblast-like cells originate from rat bone sacroma. ${ }^{24}$ These cells are reported to contain a large proportion of proliferative, phenotypically immature cells, closely resembling progenitor cells, and ongoing maturation of these cells may be responsible for the increase in ALP activity and hormones, and responsiveness to growth factors. ${ }^{25}$ Glucocorticoids are reportedly responsible for regulation of ALP activity in bone-cell culture. They may increase ALP levels up to sevenfold in ROS $17 / 2.8$ culture. ${ }^{26}$ This effect has been associated with reduced cell growth. ${ }^{27}$ Recent evidence has emerged that dexamethasone (Dex) has a specific activity on ALP gene expression..$^{28} \beta$ Glycerophosphate (GP) is required for mineralization in several bone cell or tissue culture systems in vitro. Although its mechanism is still unclear, it is generally thought that GP is a source of inorganic phosphate ions (Pi) ${ }^{29}$ When GP is added to the bone-cell culture, it may be hydrolyzed by ALP giving a high level of $\mathrm{Pi}$ in a local environment. This elevated Pi may thereby provide the chemical potential for mineral deposition. ${ }^{30}$ In our cell culture system, 100nM Dex and 10mM GP in F-12 medium increased ALP activity and its gene expression, and promoted the matrix calcification (Figs. 1 and 2). These observations make ROS 17/2.8 cells a suitable model for cytotoxicity as well as cell differentiation studies.

The cytotoxicity rank as determined by the SDH assay of the six metal ions in this study was in the following order: $\mathrm{V}^{+3}>\mathrm{Ti}^{+4}, \mathrm{Co}^{+2}>\mathrm{Ni}^{+2}>\mathrm{Cr}^{+3}, \mathrm{Al}^{+3}$. In general, this rank is similar to other results determined in other types of cell cultures. Wataha demonstrated the cytotoxicity rank order of several metal ions by Balb/c $3 \mathrm{~T} 3$ cell line as: $\mathrm{V}^{+3}>\mathrm{Co}^{+2}>\mathrm{Ni}^{+2}>\mathrm{Ti}^{+4}$

TABLE II

Effects of Six Metal Ions on ROS 17/2.8 Cell Metabolism and Gene Expression

\begin{tabular}{|c|c|c|c|c|c|c|c|}
\hline \multirow{2}{*}{\multicolumn{2}{|c|}{ Ion Conc. $(\mu \mathrm{mol} / \mathrm{L})^{*}$}} & \multicolumn{3}{|c|}{ Cell Activity $(\%)^{\dagger}$} & \multicolumn{3}{|c|}{ Osteogenic Gene Expression ${ }^{\ddagger}$} \\
\hline & & DNA Synth. & SDH Activity & ALP Activity & ALP & OCN & OPN \\
\hline \multirow[t]{2}{*}{$\mathrm{Al}^{+3}$} & 195 & $122^{\S}$ & $92^{\S}$ & $91^{\S}$ & + & + & ++ \\
\hline & 3120 & 52 & 82 & 85 & - & \pm & ++ \\
\hline \multirow[t]{2}{*}{$\mathrm{Co}^{+2}$} & 13 & 57 & 64 & 65 & ++++ & ++++ & $+++/++$ \\
\hline & 104 & 12 & 55 & 46 & + & ++ & $+++/++$ \\
\hline \multirow[t]{2}{*}{$\mathrm{Cr}^{+3}$} & 120 & 103 & 97 & 126 & ++++ & ++ & $+++/++$ \\
\hline & 1920 & 55 & 106 & 106 & + & - & - \\
\hline \multirow[t]{2}{*}{$\mathrm{Ni}^{+2}$} & 76 & 13 & 88 & 66 & ++++ & + & +++ \\
\hline & 304 & 10 & 48 & 22 & - & - & - \\
\hline \multirow[t]{2}{*}{$\mathrm{Ti}^{+4}$} & 26 & 37 & 117 & 92 & ++ & +++ & ++ \\
\hline & 104 & 11 & 42 & 53 & ++ & ++ & ++ \\
\hline \multirow[t]{2}{*}{$\mathrm{V}^{+3}$} & 5 & 36 & 90 & 88 & ++ & +++ & ++ \\
\hline & 20 & 20 & 42 & 57 & ++++ & ++++ & +++ \\
\hline \multicolumn{2}{|c|}{ Control } & 100 & 100 & 100 & ++++ & ++++ & ++++ \\
\hline
\end{tabular}

*The low concentration had low cytotoxicity and the high concentration had high cytotoxicity as determined by SDH activity. †Percentage of control (without addition of metal ions).

拉etermined by comparing the visual band density of sample with control sample (without addition of metal ions).

s The error for the mean is about $15 \%$. 
$>\mathrm{Cr}^{+3}, \mathrm{Al}^{+3} \cdot{ }^{13}$ Takeda reported the cytotoxic order to L-929 cell line by extracted solutions of pure metals as: $\mathrm{Cr}>\mathrm{Co}>\mathrm{V}>\mathrm{Ni}>\mathrm{Ti}, \mathrm{Al}^{31}$ Comparing these results, there is a common agreement about the toxic order of $\mathrm{V}, \mathrm{Co}, \mathrm{Ni}$, and $\mathrm{Al}$, but there are also several differences. The $\mathrm{TC}_{50}$ value of $\mathrm{Ti}$ is $1050 \mu \mathrm{M} / \mathrm{L}$ for the Balb/c 3T3 cell line, but only $200 \mu \mathrm{M} / \mathrm{L}$ for the ROS $17 / 2.8$ osteoblast-like cell line. This is an order of magnitude difference and suggests that the osteoblast is more sensitive to titanium than the fibroblast. The second difference is that the $\mathrm{Cr}$ was listed as the most toxic element in the group of metals by Takeda. This difference may be explained by the existence of a hexavalent form of $\mathrm{Cr}$ in Takeda's cell-culture test, since $\mathrm{Cr}^{+6}$ is more toxic than $\mathrm{Cr}^{+3}{ }^{32,33}$ Finally, aluminum is considered a toxic element to several tissues including bone, ${ }^{34}$ kidney, liver ${ }^{35}$ and brain. ${ }^{36}$ However, the results of present study indicated little cytotoxicity of $\mathrm{Al}$ in ROS 17/2.8 cells. This low cytotoxicity of $\mathrm{Al}$ in vitro has been observed in other studies. ${ }^{13}$ The reason for variation in cytotoxicity is not known. There has been a report of long-term cytotoxicity of $\mathrm{Al}$, indicating that exposure time may play a key role in $\mathrm{Al}$ cytotoxicity. ${ }^{37}$

Comparing the data in Figure 3 with $\mathrm{TC}_{50}$ values from pilot studies (Table I), it was found that the $\mathrm{Cr}$ ion at the established $\mathrm{TC}_{50}$ concentration did not cause a $50 \%$ reduction of SDH activity, and that other ions did cause a $50 \%$ reduction of SDH at lower concentrations than expected. The reason might be that the $\mathrm{TC}_{50}$ value in the pilot study was for $24 \mathrm{~h}$, compared to $72 \mathrm{~h}$ for this study. To promote cell differentiation and mineralization, AA, GP, and Dex were introduced into the culture medium from days 7 to 10 after plating. These agents could also alter the cell metabolism and sensitivity to metal ions.

As judged by SDH activity and DNA synthesis, the $\mathrm{Cr}$ and $\mathrm{Al}$ ions had low cytotoxicity within the concentrations tested. However, $\mathrm{Ni}, \mathrm{Co}, \mathrm{Ti}$, and $\mathrm{V}$ were highly cytotoxic and their effects on cell viability were a function of their concentrations. Compared with SDH activity results, the DNA synthesis rate was the more sensitive assay. However, these cytotoxicity evaluation assays cannot totally explain cell-specific functions and cell differentiation processes for ROS 17/2.8 cells. For example, metabolic tests cannot show how the ions cause preosteoblasts and young osteoblasts to differentiate into mature osteoblasts. To answer these questions, it is necessary to determine the effects of these ions on the cellular differentiation processes. In the current study, ALP, OCN, and OPN were selected as markers for observing the process of cell differentiation and mineralization. ALP is highly expressed in osteoblasts and other mineral tissues. Its functions in these tissues are not identified, but it is commonly recognized that it is related to the mineralization process in mineral tissues. ${ }^{38} \mathrm{OCN}$ (bone gla protein) has high affinity to $\mathrm{Ca}$ or $\mathrm{HA}^{39}$ and may function in mainte- nance and resorption of bone tissue by control of recruitment and differentiation of osteoclasts. ${ }^{40}$ Further study has demonstrated that OCN expression occurs only when osteoblasts differentiate from stem cells or preosteoblasts to mature osteoblasts. ${ }^{41}$ OPN also has high affinity to HA as well as collagen, ${ }^{42,43}$ and functions in the attachment of osteoblasts to surrounding calcified matrix. ${ }^{44}$ The synthesis of OPN can be detected at all developmental stages of osteoblast differentiation. ${ }^{45}$

For $\mathrm{Cr}$ and $\mathrm{Ni}$, the reduction of expression of these genes was proportional to the metal ion's concentrations. The threshold level of inhibition for gene expression was not determined, but was between 120 and $1920 \mu \mathrm{mol} / \mathrm{L}$ for $\mathrm{Cr}$, and 76 and $304 \mu \mathrm{mol} / \mathrm{L}$ for $\mathrm{Ni}$. However, it seems that the effects of metal ions on ROS cell gene expression did not simply depend on metal ion concentration. $\mathrm{Al}$ had very strong effects on bone-specific gene expression, but was not especially cytotoxic at any concentration tested. In contrast, Ti and $\mathrm{V}$ at cytotoxic concentrations did not significantly suppress gene expression. Furthermore, Co ion specifically affected ALP expression at a noncytotoxic concentration without affecting the OPN expression. The current study therefore supports the hypothesis that each metal ion acts uniquely in its effects on gene expression in ROS cells.

Multiple mechanisms exist which control and regulate the transcription and translation in eukaryotic cells. ${ }^{46}$ In addition, the post-transcriptional events influence the gene expression. Most important, gene transcription does not necessarily mean that the encoded protein will be found in the cell or extracellular matrix. Any disruption of transcription could lead to an abnormal or dysfunctional protein molecule. These experiments go a step beyond cytotoxicity testing to the level of gene expression. The results of this study allowed us to observe that the metal ions affected some of these processes. Generally, these effects could not be predicted from the cytotoxicity assays. However, the results raise new questions as to the nature of the interaction between the metal ions and various mechanisms of transcription control. For example, $\mathrm{Cr}$ and $\mathrm{Al}$ significantly suppressed ALP gene expression, but did not change ALP activity in ROS cells. The explanation for this may be that ALP activity of ROS cells was measured by a histochemistry method which measured all ALP isoenzyme activities. Each isoenzyme has its own genetic expression mechanism. The Northern blot analysis in this study was based upon only one specific ALP gene. This fact may explain the different results by the two different testing methods. However, the data may also indicate that the mRNA transcription process of this ALP is very sensitive to the presence of the $\mathrm{Cr}$ and $\mathrm{Al}$ ions.

$\mathrm{Cr}^{+3}$ used in this study is recognized as having low cytotoxicity because of its membrane impermeability and biologic inactivity. ${ }^{33}$ The cell metabolism data 
agree with this statement. Interestingly, the bonespecific gene expression in the presence of $\mathrm{Cr}^{+3}$ was substantially suppressed even though the metabolism data showed that the highest concentration caused a $50 \%$ reduction of the DNA synthetic rate as the only metabolic effect. This result implies that we should reconsider the biologic behaviors of $\mathrm{Cr}^{+3}$ especially on cellular differentiation processes. Another finding was that Ti ions suppressed ALP gene expression at toxic and nontoxic concentrations to the same degree, but the ALP activity at the toxic concentration was $52 \%$ of control, while the ALP activity at nontoxic concentration was $92 \%$ level of control. There is about a $40 \%$ difference of ALP activity in culture cells between these two tested concentrations. These findings suggest that for Ti ions inhibition might start after transcription or in translation. For example, a recent study has shown that aluminum ions can interact with elements of signal transduction pathways [i.e., bind to the guanine nucleotide-binding proteins ( $G$ protein) and a phosphatidylinositol-4-5 diphosphate (PIP $)^{-}$ specific phospholipase $\mathrm{C}]$.

In this study, we have investigated the effects of metal ions on osteoblast-like cell metabolism and differentiation, and the findings show that metal ions may affect cellular metabolism and cellular differentiation by different mechanisms at sublethal concentrations. The results have shown that the inhibition of the gene expression is ion specific, gene specific, and concentration related. Furthermore, this inhibition is not predictable based on the cellular metabolism activity. However, the mechanisms for the gene suppression are complex and the results of this study only begin to clarify mechanisms. In addition, it is important to remember that in vivo, alloys containing $\mathrm{Ti}, \mathrm{Co}$, and $\mathrm{Al}$ frequently have passavated surfaces from which very few ions are released in the environment. For the concentrations of ions released, we would expect the results described in this study. For a comprehensive understanding of the biologic actions of the metal ions, it is important to know the concentration of ions released as well as transportation pathways of metal ions through the plasma membrane and between cellular organelles. Information about reactions between biologic moleculars and metal ions is also needed.

The authors thank Dr. R. T. Franceschi and Y. Q. Cui for their generous donation of DNA probes and technique support for the Northern blot analysis. This study was supported in part by NIDR Grant P50DE09296.

\section{References}

1. A. B. Ferguson, J. Y. Akshoshi, P. G. Laing, and E. S. Holdge, "Characteristics of trace ions released from em- bedded metal implants in rabbit," J. Bone Joint Surg. 44, 323-336 (1962)

2. H. S. Dobbs and M. J. Minski, "Metal ion release after total hip replacement," Biomaterials, 1, 193-198 (1980).

3. R. J. Solar, S. R. Pollack, and E. Korostoff, "In vitro corrosion testing of titanium surgical implant alloys: An approach to understanding titanium release from implants," J. Biomed. Mater. Res., 13, 217-250 (1979).

4. A. Koegel and J. Menchim, "Release of corrosion products by F-15 cobalt base alloy in the rat. I: Acute serum elevations," J. Biomed. Mater. Res., 18, 513-522 (1984).

5. T. J. Jorgensen, F. Munno, T. G. Mitchell, and D. Hungerford, "Urinary cobalt level in patients with porous Austin-Moore prostheses," Clin. Orthop., 176, 124-126 (1983).

6. R. Owen, G. Meachim, and D. F. Williams, "Hair sampling for chromium content following Charnleg hip arthroplasty," J. Biomed. Mater. Res., 10, 91-99 (1976).

7. D. A. Jones, H. K. Lukas, M. O'Driscol, C. H. Price, and B. Wibberley, "Cobalt toxicity after McKee hip arthroplasty," J. Bone Joint Surg., 57, 289-296 (1975).

8. S. J. Lugowski, D. C. Smith, A. D. McHugh, and J. C. Van Loon, "Release of metal ions from dental implant materials in vivo: Determination of $\mathrm{Al}, \mathrm{Co}, \mathrm{Cr}, \mathrm{Mo}, \mathrm{Ni}$, $\mathrm{V}$, and Ti in organ tissue," J. Biomed. Mater. Res., 25, 1443-1458 (1991).

9. E. Smethurst and R. B. Waterhouse, "A physical examination of orthopaedic implants and adjacent tissue," Acta Orthop. Scand., 49, 8-18 (1978).

10. H. Schliephake, G. Reiss, R. Urban, F. W. Neukam, and S. Gucked, "Metal release from titanium fixture during placement in the mandible: An experimental study," Int. J. Oral Maxillofac. Implants, 8, 502-511 (1993).

11. Z. L. Sun, J. C. Wataha, and C. T. Hanks, " $\mathrm{Ti}^{+4}$ and $\mathrm{Co}^{+2}$ effects on ROS 17/2.8 osteoblastic-like cell metabolism in vitro," J. Dent. Res., 72, 390 (1993) (Abstr.).

12. Z. L. Sun, J. C. Wataha, and C. T. Hanks, "Effects of metal ions on ROS $17 / 2.8$ cell metabolism," J. Dent. Res., 73, 400 (1994) (Abstr.).

13. J. C. Wataha, C. H. Hanks, and Z. L. Sun, "Effect of cell line on in vivo metal ion cytotoxicity," Dent. Mater., 10, 156-161 (1994).

14. D. R. Haynes, S. D. Rogers, S. Hay, M. J. Pearcy, and D. W. Howie, "The differences in toxicity and release of bone-resorbing mediators induced by titanium and cobalt-chromium-alloy wear particles," J. Bone Joint Surg. Am., 75, 825-834 (1993).

15. R. Massas, S. Pitaru, and M. M. Weinreb, "The effects of titanium and hydroxyapatite on osteoblastic expression and proliferation in rat parietal bone cultures," J. Dent. Res., 72, 1005-1008 (1993).

16. D. A. Puleo, K. E. Preston, J. B. Shuffer, and R. Bizios, "Examination of osteoblast orthopaedic biomaterial interactions using molecular techniques," Biomaterials, 14, 111-114 (1993).

17. C. T. Hanks, S. E. Strawn, J. C. Wataha, and R. G. Craig, "Cytotoxic effects of resin components on cultured mammalian fibroblasts," J. Dent. Res., 70, 1450-1455 (1991).

18. J. C. Wataha, C. T. Hanks, and R. G. Craig, "In vitro synergistic, antogonistic, and duration of exposure effects of metal cations on eukaryotic cells," J. Biomed. Mater. Res., 26, 1297-1309 (1992).

19. M. P. Mark, W. T. Butler, C. W. Prince, R. D. Finkelman, and J.-V. Ruch, "Development expression of $44 \mathrm{kDa}$ bone phosphoprotein (osteopontin) and bone gammacarboxyglutamic acid (Gla)-containing protein (osteo- 
calcin) in calcifying tissues of rat," Differentiation, 37, 123-136 (1988).

20. L. F. Congote, J. Theberge, L. Mazza, and Q. Li, “Assay for thymidine incorporation into anchorage dependent or independent cells without filtration or cell harvesting," J. Tissue Cult. Methods, 12, 14-51 (1989).

21. A. G. Pearse, ed., Histochemistry: Theretical and Applied, Vol. 2, Williams and Wikins, Baltimore, 1972, Chapter 20.

22. O. A. Bessey, O. H. Lowry, and M. J. Brok, "A method for the rapid determination of alkaline phosphatase with five cubic milliliters of serum," J. Biol. Chem., 164, 321-329 (1946).

23. H. C. Towle, C. N. Marish, and J. H. Oppenheimer, "Changes in hepatic levels of messenger ribonucleic acid for malic enzyme during induction by thyroid hormone or diet," Biochemistry, 19, 579-585 (1980).

24. R. J. Majeska, S. B. Rodan, and G. A. Rodan, "Parathyroid hormone responsive clonal cell lines from rat osteosarcoma," Endocrinology, 107, 1494-1497 (1980).

25. R. J. Majeska, B. C. Nair, and G. A. Rodan, "Glucocorticoid regulation of alkaline phosphatase in the osteoblastic osteosarcoma cell line ROS 17/2.8," Endocrinology, 116, 170-179 (1985).

26. S. B. Rodan, M. Fischer, J. Egan, P. Epstein, and G. A. Rodan, "The effect of dexamethasone on parathyroid hormone stimulation of adenylate cyclase in ROS 17/ 2.8 cells," Endocrinology, 115, 951-958 (1984).

27. T. A. Chen, L. Aronow, and D. Feldman, "Glucocorticoid receptor and inhibition of bone cell growth in primary culture," Endocrinology, 100, 619-625 (1977).

28. E. Green, T. Todd, and D. Heath, "Mechanism of glucocorticoid regulation of alkaline phosphatase gene expression in osteoblast-like cells," Eur. J. Biochem., 188, 147-153 (1990).

29. H. C. Tenenbaum, "Role of organic phosphate in mineralization of bone in vitro," J. Dent. Res., 60, 1586-1589 (1981).

30. C. H. Chung, E. E. Golub, E. Forbes, T. Tokuoka, and I. M. Shapiro, "Mechanism of action of $\beta$-glycerophosphate on bone cell mineralization," Calcif. Tissue Int., 51, 305-311 (1992).

31. S. Takeda, H. Kakiuchi, H. Doi, and M. Nakamura, "Cytotoxicity of pure metals," Shika Zairyo Kikai, 8, 648652 (1989).

32. G. Axelsson and R. Rylander, "Environmental chromium dust and lung cancer mortality," Environ. Res., 23, 469-476 (1980).

33. D. Shapcott, "Measurement of the uptake of chromatin," in Biocompatibility of Co-Cr-Ni Alloys, H. F. Hilde- brand and M. Champy (eds.), Plenum Press, New York, 1988, pp. 31-44.

34. H. H. Malluche and M. C. Faugere, "Aluminum-related bone disease," Blood Purif., 6, 1-15 (1988).

35. G. Stein, V. Laske, A. Muller, H. Braunlich, W. Linss, and C. Fleck, "Aluminum induced damage of the lysosomes in the liver, spleen and kidneys of rats," J. Appl. Toxicol., 7, 253-258 (1987).

36. A. Bilkei-Gorzo, "Neurotoxic effect of enteral aluminium," Food Chem. Toxicol., 31, 357-361 (1993).

37. P. O. Ganrot, "Metabolism and possible health effects of aluminum," Environ. Health Perspect., 65, 363-441 (1986).

38. B. de Bernard, P. Bianco, E. Bonucci, M. Costantini, G. C. Lunazzi, P. Martinuzzi, C. Modricky, L. Moro, E. Panfili, P. Pollesello, N. Stagni, and F. Vitlur, "Biochemical and immunohistochemical evidence that in cartilage an alkaline phosphatase is a $\mathrm{Ca}^{2+}$ binding glycoprotein," J. Cell Biol., 103, 1615-1618 (1986).

39. P. V. Hauschka, "Osteocalcin and its functional domains," in The Chemistry and Biology of Mineralized Tissues, W. T. Butler (ed.), Ebsco Media, Birmingham, AL, 1992, pp. 149-158.

40. G. R. Mundy and J. W. Poser, "Chemotactic activity of the gamma-carboxyglutamic acid containing protein in bone," Calcif. Tissue Int., 35, 164-168 (1993).

41. J. Lian and G. S. Stein, "Concepts of osteoblast growth and differentiation: Basis for modulation of bone cell development and tissue formation: Critical reviews," Oral Biol. Med., 3, 269-305 (1992).

42. W. T. Butler, "The nature and significance of osteopontin," Connect. Tissue Res., 23, 123-136 (1989).

43. Y. Chen, B. S. Bal, and J. D. Gorski, "Calcium and collagen binding properties of osteopontin, bone sialoprotein, and bone acidic glycoprotein-75 from bone," J. Biol. Chem., 267, 24871-24878 (1992).

44. A. Oldlerg, A. Franzen, and D. Heinegard, "Cloning and sequence analysis of rat bone sialoprotein (osteopontin) cDNA reveals a Arg-Gly-Asp cell binding sequence," Proc. Natl. Acad. Sci. USA, 83, 8819-8823 (1986).

45. A. Sutt, H. Mayer, and E. Wingender, "New perspectives in the differentiation of bone-forming cells," Biofactors, 4, 1-13 (1992).

46. B. Albert, D. Bray, J. Lewis, M. Raff, K. Robert, and J. D. Watson, eds., Molecular Biology of the Cell, 3rd ed., Garland Publishing, New York, 1994.

47. A. Haug, B. Shi, and V. Vitorello, "Aluminum interaction with phosphoinositide-associated signal transduction," Arch. Toxicol., 68, 1-7 (1994).

Received October 4, 1995

Accepted February 19, 1996 